\title{
HYDROFINING OF PETROL FRACTIONS OF OIL ON MODIFIED ALUMINA CATALYSTS
}

\author{
B.T. Tuktin ${ }^{1}$, A.S. Tenizbayeva ${ }^{1}$, A.A. Omarova ${ }^{2}$, L.R. Sassykova ${ }^{2, *}$ \\ and Zh.A. Sailau ${ }^{1}$ \\ ${ }^{1}$ D.V.Sokolsky Institute of Fuel, Catalysis \& Electrochemistry, 142, D. Kunaev Str., \\ Almaty-050010, Kazakhstan, \\ ${ }^{2}$ Al-Farabi Kazakh National University, 71, al-Farabi Ave., Almaty-050040, Kazakhstan. \\ *E-mail: larissa.rav@mail.ru
}

\begin{abstract}
The paper describes the study of the gasoline fraction hydrofining on the zeolite-containing alumina catalysts modified with variable valence metals, additives of phosphorus and a rare-earth element. In this work, the new zeolite-containing alumina catalysts were developed: $\mathrm{NiO}-\mathrm{MoO}_{3}$-E-P-HZSM-HY- $\mathrm{Al}_{2} \mathrm{O}_{3}, \mathrm{CoO}-\mathrm{MoO}$-E-P-HZSM$\mathrm{HY}-\mathrm{Al}_{2} \mathrm{O}_{3}$ and $\mathrm{CoO}-\mathrm{WO}_{3}-\mathrm{E}-\mathrm{P}-\mathrm{Al}_{2} \mathrm{O}_{3}-\mathrm{ZSM}$, where $\mathrm{E}$ is a rare-earth element. The research was carried out under high-pressure at the flow installation with a fixed catalyst bed. The smallest residual sulfur content $(0.0005 \%)$ is observed in hydrotreated gasoline on the catalyst $\mathrm{CoO}-\mathrm{WO}_{3}-\mathrm{E}-\mathrm{P}-\mathrm{HZSM}-\mathrm{HY}-\mathrm{Al}_{2} \mathrm{O}_{3}$, which is 2-4 times lower than on the catalysts $\mathrm{CoO}-\mathrm{MoO}_{3}-\mathrm{E}-\mathrm{P}-\mathrm{HZSM}-\mathrm{HY}-\mathrm{Al}_{2} \mathrm{O}_{3}$ and $\mathrm{NiO}-\mathrm{MoO}_{3}-\mathrm{E}-\mathrm{P}-\mathrm{HZSM}-\mathrm{HY}-\mathrm{Al}_{2} \mathrm{O}_{3}$ and lower than is limited by the Euro-5 standard. When tested on the $\mathrm{NiO}-\mathrm{MoO}_{3}-\mathrm{E}-\mathrm{P}-\mathrm{HZSM}-\mathrm{HY}-\mathrm{Al}_{2} \mathrm{O}_{3}$ catalyst, the octane number of the gasoline as a result of hydrotreating increased to 88.6, which is significantly higher than on other catalysts. According to electron microscopy, the catalysts are highly dispersed, the components of the active phase metals are mainly in the oxidized state, forming clusters-associates on the surface. The structure, dispersion and state of the clusters are related to the nature of the catalyst components. The synthesized catalysts make it possible to produce high-octane low-sulfur gasoline that meets European standards.
\end{abstract}

Keywords: Hydrofining, Petrol Fractions of Oil, Catalysis, Zeolite, Alumina

(C) RASĀYAN. All rights reserved

\section{INTRODUCTION}

Recently, in connection with the involvement in the processing of sour crude oil and the deepening of its processing, the requirements for catalysts for hydrotreating petroleum fractions have increased. In the world production of motor fuels, there is a constant trend of tightening their environmental performance. ${ }^{1-8}$ According to the international standards, a substantial limitation of the content of benzene, olefinic hydrocarbons, sulfur and aromatic hydrocarbons in motor fuels is required. In the oil refining industry, deep hydrotreating and hydroisomerization of the oil fractions are increasingly used to produce highquality motor fuels ${ }^{5-8}$ For carrying out deep hydrotreating of various fractions of oil, it is necessary to use new efficient catalysts and technologies. In various countries of the world, active search and development of new catalysts for the deep hydrotreatment of petroleum fractions are carried out and the technology for the production of motor fuels is being improved. ${ }^{9-11}$ In this case, more attention is paid to the development of a hydrotreating catalyst for a certain type of petroleum product. ${ }^{12-16}$

This paper presents the results of a study of the catalytic hydrofining of a gasoline fraction of oil on new alumina catalysts modified with additives of metals with variable valence, ZSM-5 zeolite, phosphorus and rare earth.

\section{EXPERIMENTAL}

In this work new zeolite-containing alumina catalysts modified by the introduction of metals with variable valence and phosphorus were developed: $\mathrm{NiO}-\mathrm{MoO}_{3}-\mathrm{E}-\mathrm{P}-\mathrm{HZSM}-\mathrm{HY}-\mathrm{Al}_{2} \mathrm{O}_{3}, \mathrm{CoO}-\mathrm{MoO}_{3}$-E-P-HZSM$\mathrm{HY}-\mathrm{Al}_{2} \mathrm{O}_{3}$ and $\mathrm{CoO}-\mathrm{WO}_{3}-\mathrm{E}-\mathrm{P}-\mathrm{Al}_{2} \mathrm{O}_{3}-\mathrm{ZSM}$, where $\mathrm{E}$ is a rare-earth element.

Rasayan J. Chem., 12(3), 1478-1484(2019)

http://dx.doi.org/10.31788/RJC.2019.1235236

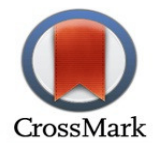


The percentage of modifying additives in the catalysts was as follows: nickel $(\mathrm{NiO})-3 \%$, molybdenum $\left(\mathrm{MoO}_{3}\right)-12 \%$, E (rare-earth element, $\left.\mathrm{Ce}_{2} \mathrm{O}_{3}\right)-1 \%$, cobalt $(\mathrm{CoO})-3 \%$, tungsten $\left(\mathrm{WO}_{3}\right)-12 \%$ and phosphorus $\left(\mathrm{P}_{2} \mathrm{O}_{5}\right)-3 \%$.

The method of preparation such catalysts was developed by the authors earlier ${ }^{16}$. The catalysts were prepared by simultaneous impregnation of a mixture of aluminum hydroxide with zeolites HZSM-5 and HY, water-soluble salts of rare-earth element (E), nickel, tungsten, cobalt, molybdenum, and also phosphoric acid. After impregnation, the samples of the catalysts were molded and dried at $150^{\circ} \mathrm{C}$ for 5 hours, then calcined at $550^{\circ} \mathrm{C}$ for 5 hours.

The activity of the synthesized catalysts was studied in the hydrofining of the gasoline fraction of oil. The process was carried out according to the method developed earlier and described in the works ${ }^{16-18}$. Hydrofining of petrol fractions of oil was performed with a flow installation fixed bed at temperatures of $320-400{ }^{\circ} \mathrm{C}$, the bulk flow rate of $2.0 \mathrm{~h}^{-1}$, pressure $4.0 \mathrm{MPa}$.

When studying the process of hydro-processing, a gasoline fraction of the following composition was used: sulfur content $0.037 \%$, aromatic hydrocarbons $5.6 \%$, paraffin $33.4 \%$, olefins $3.7 \%$, naphthenic hydrocarbons $31.0 \%$, isoalkanes $26.3 \%$; octane number was 77.7 (by the research method, RM) and 53.8 (by the motor method, MM). The hydrocarbon composition of the reaction products was determined on chromatographs "Chromatec-Crystal" (Russia) and "Agilent". Analysis of the sulfur content in the starting material and products was carried out on the SPECTROSCAN Instrument. The physicochemical characteristics of the catalysts were studied using electron microscopy (TEM), BET method and TPD of ammonia. $^{19,20}$

\section{Hydrofining of Petrol Fractions}

\section{RESULTS AND DISCUSSION}

During hydro processing of the gasoline fraction on the NiO- $\mathrm{MoO}_{3}-\mathrm{E}-\mathrm{P}-\mathrm{HZSM}-\mathrm{HY}-\mathrm{Al}_{2} \mathrm{O}_{3}$ catalyst at $320^{\circ} \mathrm{C}$, the content of isoalkanes increases from 26.3 to $40.3 \%$. With further increase in temperature to $400^{\circ} \mathrm{C}$, their amount reaches a maximum value of $44.9 \%$ (Table-1). The yield of the liquid phase in the range of $320-400^{\circ} \mathrm{C}$ decreases with increasing temperature from 98.1 to $88.5 \%$, which is associated with hydrocracking strengthening. Under these conditions, the share of aromatic hydrocarbons in the final product increases from 7.6 to $15.4 \%$, the content of naphthenic hydrocarbons decreases from $31.0 \%$ in the initial gasoline to $21.1 \%$ at $400^{\circ} \mathrm{C}$.

The concentration of olefinic hydrocarbons in the resulting final product varies slightly and is in the range of $3.5-5.2 \%$. The octane number of gasoline in these conditions grows from 77.7 (starting gasoline) to $88.6(\mathrm{RM})$ and from 53.8 to 74.1 (MM). After hydroprocessing of gasoline with an initial sulfur content of $0.037 \%$ on the catalyst $\mathrm{NiO}-\mathrm{MoO}_{3}-\mathrm{E}-\mathrm{P}-\mathrm{HZSM}-\mathrm{HY}-\mathrm{Al}_{2} \mathrm{O}_{3}$, the mass fraction of sulfur decreased to $0.0020 \%$ with an increase in temperature to $400^{\circ} \mathrm{C}$. Replacing the nickel in the catalyst with cobalt $(\mathrm{CoO}-$ $\mathrm{MoO}_{3}$-E-P-HZSM-HY- $\mathrm{Al}_{2} \mathrm{O}_{3}$ ) has little effect on the content of olefinic, aromatic hydrocarbons in the resulting products, but the amount of isoalkanes decreases, which leads to a certain decrease in the octane number. However, when the gasoline fraction is hydrotreated, the catalyst has a higher hydrodesulfurization activity compared to $\mathrm{NiO}-\mathrm{MoO}_{3}-\mathrm{E}-\mathrm{P}-\mathrm{Al}_{2} \mathrm{O}_{3}-\mathrm{ZSM}$ : the residual sulfur content in gasoline treated at $400^{\circ} \mathrm{C}$ is $0.0010 \%$ (Table-1).

Table-1: Hydro-processing of the gasoline fraction on the synthesized catalysts at $\mathrm{P}=4.0 \mathrm{MPa}, \mathrm{V}=2.0 \mathrm{~h}^{-1}$

\begin{tabular}{c|c|c|c|c}
\hline \multirow{2}{*}{ The composition of the reaction products, $\%$} & \multicolumn{5}{|c}{ Process temperature, ${ }^{\circ} \mathrm{C}$} \\
\cline { 2 - 5 } & 320 & 350 & 380 & 400 \\
\hline Catalyst - NiO- $\mathrm{MoO}_{3}$-E-P-HZSM-HY- $\mathrm{Al}_{2} \mathrm{O}_{3}$ & & \multicolumn{3}{c}{1} \\
\hline Paraffins & 24.1 & 22.3 & 16.4 & 15.1 \\
\hline Isoalkanes & 40.3 & 43.4 & 44.8 & 44.9 \\
\hline Olefins & 4.0 & 3.9 & 5.2 & 3.5 \\
\hline Aromatic Hydrocarbons & 7.6 & 11.6 & 13.1 & 15.4 \\
\hline Naphthenic Hydrocarbons & 24.0 & 18.8 & 20.5 & 21.1 \\
\hline
\end{tabular}


RASĀYAN J. Chem.

Vol. 12 | No. 3 |1478 - 1484| July - September | 2019

\begin{tabular}{|c|c|c|c|c|}
\hline Yield of liquid phase, $\%$ & 98.1 & 97.2 & 95.3 & 88.5 \\
\hline Octane number by a research method & 81.5 & 84.3 & 86.1 & 88.6 \\
\hline Octane number by a motor method & 66.9 & 70.5 & 72.1 & 74.1 \\
\hline Sulfur content, $\%$ & 0.0177 & 0.010 & 0.00810 & 0.0020 \\
\hline \multicolumn{5}{|c|}{ Catalyst - CoO- $\mathrm{MoO}_{3}$-E-P-HZSM-HY- $\mathrm{Al}_{2} \mathrm{O}_{3}$} \\
\hline Paraffins & 31.3 & 28.7 & 20.0 & 18.7 \\
\hline Isoalkanes & 28.2 & 29.2 & 31.0 & 39.8 \\
\hline Olefins & 3.9 & 4.3 & 4.2 & 3.6 \\
\hline Aromatic Hydrocarbons & 7.7 & 9.8 & 11.8 & 16.9 \\
\hline Naphthenic Hydrocarbons & 28.9 & 28.0 & 28.6 & 21.0 \\
\hline Yield of liquid phase, $\%$ & 97.0 & 95.0 & 92.0 & 89.0 \\
\hline Octane number by a research method & 78.2 & 79.5 & 80.3 & 82.7 \\
\hline Octane number by a motor method & 53.5 & 53.9 & 56.1 & 58.9 \\
\hline Sulfur content, $\%$ & 0.019 & 0.009 & 0.0030 & 0.0010 \\
\hline \multicolumn{5}{|c|}{ Catalyst - CoO-WO $3-\mathrm{E}-\mathrm{P}-\mathrm{HZSM}-\mathrm{HY}-\mathrm{Al}_{2} \mathrm{O}_{3}$} \\
\hline Paraffins & 24.9 & 20.9 & 20.0 & 14.4 \\
\hline Isoalkanes & 29.9 & 36.3 & 38.1 & 41.1 \\
\hline Olefins & 3.4 & 3.4 & 3.8 & 4.0 \\
\hline Aromatic Hydrocarbons & 12.1 & 15.3 & 18.5 & 19.8 \\
\hline Naphthenic Hydrocarbons & 29.7 & 24.1 & 19.6 & 20.7 \\
\hline Yield of liquid phase, $\%$ & 96.0 & 93.0 & 90.0 & 87.9 \\
\hline Octane number by a research method & 84.6 & 85.4 & 85.6 & 86.1 \\
\hline Octane number by a motor method & 65.5 & 68.1 & 68.6 & 68.9 \\
\hline Sulfur content, $\%$ & 0.003 & 0.0010 & 0.0007 & 0.0005 \\
\hline
\end{tabular}

When hydroprocessing of the gasoline fraction on the catalyst CoO- $\mathrm{WO}_{3}$-E-P-HZSM-HY- $\mathrm{Al}_{2} \mathrm{O}_{3}$ at 320 $400^{\circ} \mathrm{C}$ the amount of isoalkanes and aromatic hydrocarbons increased from 26.3 to 29.9-41.1 compared with the initial \% and from 5.6 to $12.1-19.6 \%$, respectively (Table-1). The content of naphthenic hydrocarbons decreases from 31.0 to $29.7-19.6 \%$. The octane number of the gasoline produced at a temperature of $320^{\circ} \mathrm{C}$ is equal to $84.6(\mathrm{RM})$ and $68.1(\mathrm{MM})$. With an increase in temperature, the octane number of the gasoline produced increases and, at $400^{\circ} \mathrm{C}$, is $86.1(\mathrm{RM})$ and $68.9(\mathrm{MM})$. It should be noted that in gasoline hydrofined on the catalyst $\mathrm{CoO}-\mathrm{WO}_{3}-\mathrm{E}-\mathrm{P}-\mathrm{HZSM}-\mathrm{HY}-\mathrm{Al}_{2} \mathrm{O}_{3}$ at $350^{\circ} \mathrm{C}$, the sulfur content is $0.0010 \%$, and at $400^{\circ} \mathrm{C}$ the sulfur content in gasoline is $0.0005 \%$, which indicates a high hydrodesulfurization activity of this catalyst: the degree of hydrodesulfurization reaches $98.7 \%$.

A comparison of the obtained results shows that during hydro processing of the gasoline fraction at $400^{\circ} \mathrm{C}$ and the flow rate of the raw material from $2.0 \mathrm{~h}^{-1}$, the hydrodesulfurization activity changes in a series of catalysts: CoO- $\mathrm{WO}_{3}$-E-P-HZSM-HY- $\mathrm{Al}_{2} \mathrm{O}_{3}(0.0005 \%)<\mathrm{CoO}-\mathrm{MoO}_{3}$-E-P-HZSM-HY- $\mathrm{Al}_{2} \mathrm{O}_{3}(0.0010 \%)<$ $\mathrm{NiO}-\mathrm{MoO}_{3}$-E-P-HZSM-HY- $\mathrm{Al}_{2} \mathrm{O}_{3}(0.0020 \%)$.

Thus, the smallest residual sulfur content $(0.0005 \%)$ is observed in hydrotreated gasoline obtained on the catalyst $\mathrm{CoO}-\mathrm{WO}_{3}$-E-P-HZSM-HY- $\mathrm{Al}_{2} \mathrm{O}_{3}$, which is 2-4 times lower than on the catalysts $\mathrm{CoO}-\mathrm{MoO}_{3}-\mathrm{E}-$ P-HZSM-HY- $\mathrm{Al}_{2} \mathrm{O}_{3}$ and NiO- $\mathrm{MoO}_{3}$-E-P-HZSM-HY- $\mathrm{Al}_{2} \mathrm{O}_{3}$ and lower than that required by the Euro-5 standard. The octane number after hydrotreating on the NiO- $\mathrm{MoO}_{3}$-E-P-HZSM-HY- $\mathrm{Al}_{2} \mathrm{O}_{3}$ catalyst increases to 88.6 , which is higher than on other catalysts: $\mathrm{NiO}-\mathrm{MoO}_{3}-\mathrm{Ce}-\mathrm{P}-\mathrm{HZSM}-\mathrm{HY}-\mathrm{Al}_{2} \mathrm{O}_{3}(88.6)>$ 
$\mathrm{CoO}-\mathrm{WO}_{3}$-Ce-P-HZSM-HY- $\mathrm{Al}_{2} \mathrm{O}_{3}(86.1)>\mathrm{CoO}-\mathrm{MoO}_{3}$-Ce-P-HZSM-HY- $\mathrm{Al}_{2} \mathrm{O}_{3}$ (82.7), mainly due to its high hydroisomerizing activity: the amount of isoalkanes in the final sample was $44.9 \%$ (Table-1).

On all studied catalysts, the octane number of the gasoline fraction increases with temperature, mainly due to the aromatization and isomerization of n-alkanes, as well as a small degree of hydrocracking. It is noticed that with an increase in the reaction temperature, a decrease in the yield of hydrotreated gasoline is observed. This phenomenon, probably, can be explained by the increase in the share of hydrocracking and, as a consequence, the formation of gaseous products.

\section{Physicochemical Research of the Synthesized Catalysts}

Using the BET method, it was found that the surface of the developed catalysts varies within 211.0-274.0 $\mathrm{m}^{2} / \mathrm{g}$ of catalyst. Catalysts are characterized by pores with $\mathrm{d} \approx 1.5-2.5 \mathrm{~nm}$ and with $\mathrm{d} \approx 7.0 \mathrm{~nm}$. The total pore volume of the catalysts does not exceed $0.28-0.41 \mathrm{ml} / \mathrm{g}$ of catalyst.

From the scientific literature, it is well known that acid-base characteristics of the catalysts are essential for the process of hydrocarbon processing ${ }^{21-25}$. Acid characteristics of the developed catalysts were investigated by the method of temperature-programmed desorption of ammonia (Table-2).

Table-2: Acid-Basic Characteristics of Catalysts

\begin{tabular}{|c|c|c|c|c|c|}
\hline \multirow[t]{2}{*}{ Catalyst } & \multicolumn{2}{|c|}{$\begin{array}{c}\text { Maximum Peak } \\
\text { Temperature, } \\
{ }^{\circ} \mathrm{C}\end{array}$} & \multicolumn{2}{|c|}{$\begin{array}{l}\text { Amount of Desorbed } \\
\text { Ammonia, } 10^{-4} \text {, mol } \\
\mathrm{NH}_{3} \text { des/g Catalyst }\end{array}$} & \multirow[t]{2}{*}{$\begin{array}{c}\Sigma \mathrm{NH}_{3 \text { des }} \cdot 10^{-4} \mathrm{~mol} / \mathrm{g} \\
\text { Catalyst }\end{array}$} \\
\hline & 1 & 2 & 1 & 2 & \\
\hline $\mathrm{CoO}-\mathrm{WO}_{3}$-E-P-HZSM-HY- $\mathrm{Al}_{2} \mathrm{O}_{3}$ & - & 210 & - & 26.0 & 26.0 \\
\hline $\mathrm{NiO}-\mathrm{MoO}_{3}$-E-P-HZSM-HY- $\mathrm{Al}_{2} \mathrm{O}_{3}$ & - & 215 & - & 31.3 & 31.3 \\
\hline $\mathrm{CoO}-\mathrm{MoO}_{3}$-E-P-HZSM-HY- $\mathrm{Al}_{2} \mathrm{O}_{3}$ & 175 & 220 & 10,2 & 9.48 & 19.8 \\
\hline
\end{tabular}

From the data presented in Table-2, it can be seen that $\mathrm{CoO}-\mathrm{WO}_{3}$-E-P-HZSM-HY- $\mathrm{Al}_{2} \mathrm{O}_{3}$ and NiO- $\mathrm{MoO}_{3}$ E-P-HZSM-HY- $\mathrm{Al}_{2} \mathrm{O}_{3}$ catalysts are characterized by the presence of acid sites with $\mathrm{T}_{\text {des }}$ equal to 210 and $215^{\circ} \mathrm{C}$, accordingly. The amount of ammonia desorbed from the $\mathrm{CoO}-\mathrm{WO}_{3}-\mathrm{E}-\mathrm{P}-\mathrm{HZSM}-\mathrm{HY}-\mathrm{Al}_{2} \mathrm{O}_{3}$ catalyst surface is $26.0 \cdot 10^{-4} \mathrm{~mol} \mathrm{NH}_{3} \mathrm{des} / \mathrm{g}$ catalyst, the concentration of acid sites on the catalyst NiO$\mathrm{MoO}_{3}$-E-P-HZSM-HY- $\mathrm{Al}_{2} \mathrm{O}_{3}$ is higher $-31.3 \cdot 10^{-4} \mathrm{~mol} \mathrm{NH}_{3}$ des/g catalyst. On the surface of the CoO$\mathrm{MoO}_{3}$-E-P-HZSM-HY- $\mathrm{Al}_{2} \mathrm{O}_{3}$ catalyst, ammonia is adsorbed in two forms with $\mathrm{T}_{\max }$ equal to 175 and $220^{\circ} \mathrm{C}$. The number of different forms of desorbed ammonia is close and amounts to 10.2 and $9.48 \mathrm{~mol}$ $\mathrm{NH}_{3}$ des/g catalyst, respectively. The total amount of chemisorbed ammonia on CoO-MoO$-\mathrm{E}-\mathrm{P}-\mathrm{HZSM}-$ $\mathrm{HY}-\mathrm{Al}_{2} \mathrm{O}_{3}$ is less than on other catalysts and is $19.69 \cdot 10^{-4} \mathrm{~mol} \mathrm{NH}_{3}$ des/g catalyst. The highest concentration of acid sites is $31.3 \cdot 10^{-4} \mathrm{~mol} \mathrm{NH}$ des/g catalyst (desorption temperature $\mathrm{T}_{\max }=215^{\circ} \mathrm{C}$ ) and it is characteristic of $\mathrm{NiO}-\mathrm{MoO}_{3}$-E-P-HZSM-HY- $\mathrm{Al}_{2} \mathrm{O}_{3}$ catalyst, which determines its higher hydroisomerization activity in the process of hydroprocessing of the gasoline fraction.

It is known that the activity of catalysts is associated with the surface structure, dispersion and state of the active centers ${ }^{16,24-27}$. TEM study of the structure and state of the active centers of the synthesized catalysts was carried out. Studies have shown that on the surface of these catalysts, there are several types of surface structures that differ significantly in both size and chemical state of the components. According to electron microscopy, the catalysts are highly dispersed, the components of the active phase metals are mainly in the oxidized state, forming clusters-associates on the surface. The structure, dispersion and state of the clusters are related to the nature of the catalyst components.

An electron microscopic study (TEM) of the catalyst CoO- $\mathrm{MoO}_{3}-\mathrm{E}-\mathrm{P}-\mathrm{HZSM}-\mathrm{HY}-\mathrm{Al}_{2} \mathrm{O}_{3}$ showed that there are small aggregates on the surface reaching 3.0-4.0 nm, identified as $\mathrm{Mo}_{3} \mathrm{Si}$ and $\mathrm{EP}$, and structures with $\mathrm{d} \approx 5.0-10.0 \mathrm{~nm}$, formed by $\mathrm{E}_{2} \mathrm{O}_{3}, \mathrm{MoSi}_{2}, \mathrm{MoP}$. Formations with $\mathrm{d} \approx 4.0-6.0 \mathrm{~nm}$, consisting of $\mathrm{AlE}_{3}$, $\mathrm{Co}_{2} \mathrm{O}_{3}, \mathrm{Co}_{2} \mathrm{SiO}_{3}, \mathrm{E}_{6} \mathrm{O}_{11}$, prevail (Fig.-1). It has been found that on the surface of the catalyst $\mathrm{NiO}-\mathrm{MoO}_{3}-$ E-P-HZSM-HY- $\mathrm{Al}_{2} \mathrm{O}_{3}$ there are small evenly spaced nano-sized $\mathrm{NiO}$ and MoNiSi particles with $\mathrm{d} \approx 4.0$ $5.0 \mathrm{~nm}$ and clusters of $\mathrm{Ni}_{2} \mathrm{O}_{3}$ particles with a size of 7.0-10.0 nm (Fig.-2). There are film-type structures 
with $\mathrm{d}=15.0 \mathrm{~nm}$, the microdiffraction pattern of which is represented by symmetrical reflexes and can be attributed to a mixture of modifications of $\mathrm{Mo}_{9} \mathrm{O}_{26}, \mathrm{MoSi}$ and $\mathrm{EMO}_{3} \mathrm{O}_{13}$.

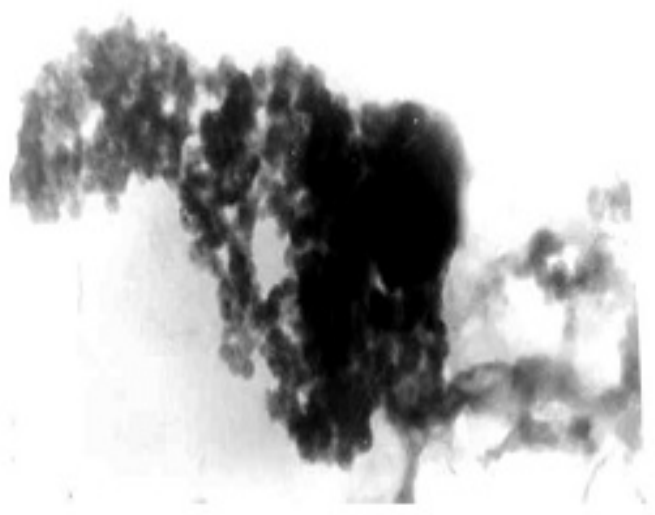

(a)

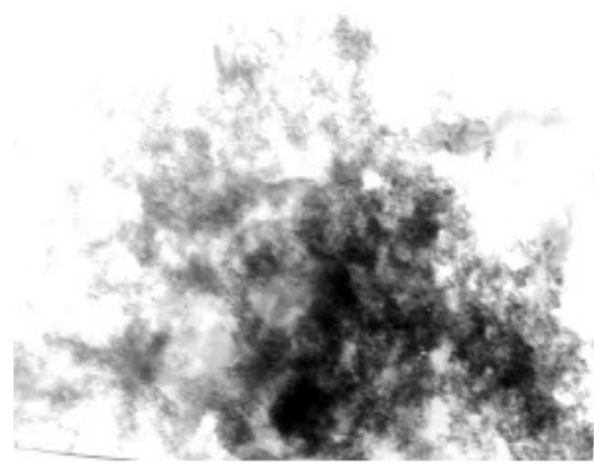

(b)

Fig.-1: TEM Images of CoO- $\mathrm{MoO}_{3}$-E-P-HZSM-HY- $\mathrm{Al}_{2} \mathrm{O}_{3}$ catalyst. The increase 80,000.

In addition, the translucent aggregates $(\mathrm{d} \approx 20.0 \mathrm{~nm})$ were found, consisting of looser small particles, which can be defined as a mixture of states including the rare earth element: $\mathrm{EO}_{2}, \mathrm{E}_{2} \mathrm{O}_{3}, \mathrm{E}\left(\mathrm{MoO}_{4}\right), \mathrm{MoP}$, $\mathrm{SiP}$, and $\mathrm{NiOOH}^{16}$. MoSi, $\mathrm{SiP}$ and MoNiSi structures were also found in the composition of the catalyst associates. This fact indicates the direct interaction of matrix atoms with modifying metals and other additives. Such formed structures can act as Lewis acid sites, which is consistent with the analysis of the thermal desorption of ammonia.

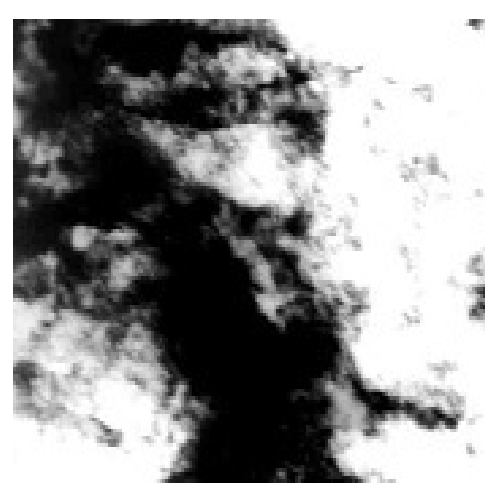

(a)

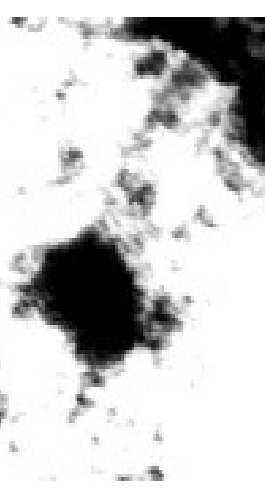

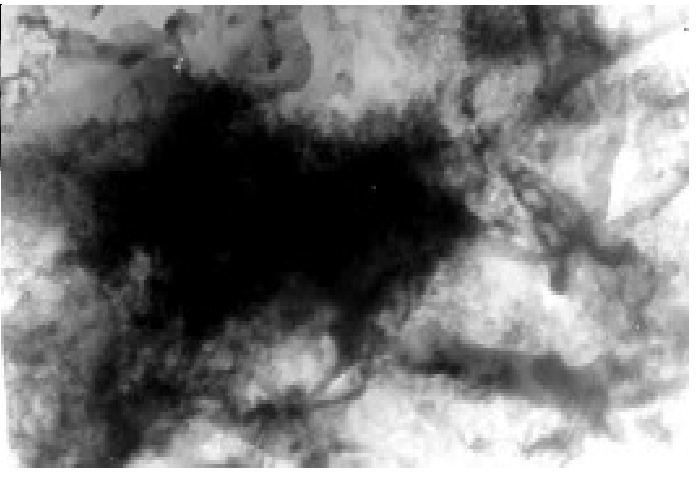

(b)

Fig.-2: TEM Images of $\mathrm{NiO}-\mathrm{MoO}_{3}$-E-P-HZSM-HY- $\mathrm{Al}_{2} \mathrm{O}_{3}$ catalyst. The increase 80,000.

On the surface of the catalyst $\mathrm{CoO}-\mathrm{WO}_{3}$-E-P-HZSM-HY- $\mathrm{Al}_{2} \mathrm{O}_{3}$, structures whose size varies in the range $\mathrm{d} \approx 2.5-3.0 \mathrm{~nm}$, consisting of $\mathrm{E}_{2} \mathrm{O}_{3}$, were found. There are clusters with $\mathrm{d} \approx 5.0 \mathrm{~nm}$ and $\approx 20.0 \mathrm{~nm}$ of highly dispersed particles $(\mathrm{d} \approx 0.20-0.25 \mathrm{~nm})$ consisting of $\mathrm{E}_{4} \mathrm{~W}_{9} \mathrm{O}_{33}$ and $\mathrm{WO}_{3}$. Also there are areas with small clusters of dense particles with $\mathrm{d} \approx 5.0-7.0 \mathrm{~nm}$, a microdiffraction pattern from which can be attributed to $\mathrm{EO}_{2}, \mathrm{CoSi}, \mathrm{AlP}$ and $\mathrm{Co}_{2} \mathrm{Si}$, and aggregates with $\mathrm{d} \approx 20.0-40.0 \mathrm{~nm}$ identified as a mixture of $\mathrm{Al}_{5} \mathrm{Co}_{2}$ and $\mathrm{Al}_{3} \mathrm{E}^{16}$.

Extensive clusters of small and large dense particles with $\mathrm{d} \approx 4.0$ and $70.0 \mathrm{~nm}$, respectively, consisting of $\mathrm{E}_{2} \mathrm{~W}_{2} \mathrm{O}_{9}$ and $\mathrm{AlE}_{3}$ were also found. Comparison of data obtained by electron microscopic studies shows that the dispersion of particles on the surface of the catalyst $\mathrm{CoO}-\mathrm{WO}_{3}-\mathrm{E}-\mathrm{P}-\mathrm{HZSM}-\mathrm{HY}-\mathrm{Al}_{2} \mathrm{O}_{3}$ is higher than that of other catalytic systems studied in this work. This is probably the reason for the high hydrodesulfurization activity of the catalyst $\mathrm{CoO}-\mathrm{WO}_{3}$-E-P-HZSM-HY- $\mathrm{Al}_{2} \mathrm{O}_{3}$.

It should be noted that the catalysts are characterized by the formation of the structures $\mathrm{AlE}_{3}, \mathrm{Al}_{5} \mathrm{Co}_{2}$, $\mathrm{Al}_{3} \mathrm{E}, \mathrm{CoSi}, \mathrm{AlP}, \mathrm{Co}_{2} \mathrm{Si}, \mathrm{SiP}_{2} \mathrm{O}_{7}, \mathrm{Ni}_{3} \mathrm{Si}, \mathrm{Ni}_{3} \mathrm{Si}_{2}, \mathrm{AlNi}_{2} \mathrm{Si}, \mathrm{NiSi}_{2}, \mathrm{Mo}_{3} \mathrm{Si}, \mathrm{MoAl}_{1.3} \mathrm{Si}_{0.4}, \mathrm{AlNi}_{3}, \mathrm{AlMo}_{3}, \mathrm{MoSi}_{2}$, 
RASĀYAN J. Chem.

Vol. 12 | No. 3 |1478 - 1484| July - September | 2019

$\mathrm{Al}_{3} \mathrm{E}, \mathrm{EAlO}_{3}, \mathrm{MoSi}_{2}, \mathrm{MoP}$, indicating the introduction of metal components of the active phase in the structure of the zeolite, with the formation of new centers that can work as Lewis acid centers. The results obtained are in good agreement with the data in the scientific literature. ${ }^{4,7,11,28-36}$

\section{CONCLUSION}

In this work, the new zeolite-containing alumina catalysts modified with variable valence metals, additives of phosphorus and rare-earth elements have been synthesized. The data obtained in the study of the process of hydro treatment of the gasoline fraction show that the developed catalysts make it possible to carry out the processes of hydrocracking, hydrotreating and hydroisomerization in one stage. As a result of the research gasoline with a high octane rating and low content of sulfur, corresponding to European standards can be obtained. Analysis of the results of electron microscopy shows that these catalysts are characterized by the simultaneous presence of acid (Brønsted and Lews), $\mathbf{M}^{0}$ or $\mathbf{M}^{\mathrm{n}+}$ - metal and mixed centers. The composition of acid centers can include metals in various degrees of oxidation, fixed both inside the zeolite cavities and on their outer side.

\section{ACKNOWLEDGMENT}

We would like to express sincere gratitude for grant financing by the scientific and technical program: No. BR05236739 "Creating the basis for the production of oil and gas processing products based on domestic technologies".

\section{REFERENCES}

1. S. M. Rigutto, R.Veen and H. Laurent, Studies in Surface Science and Catalysis, 168, 855(2007), DOI: $10.1016 / \mathrm{s} 0167-2991(07) 80812-3$.

2. N. A. Pleshakova, V. A. Tyshchenko, N.N.Tomina and A. Pimerzin, Petroleum Chemistry, 48(5), 346(2008), DOI: 10.1134/S0965544108050034.

3. J. Warnatz, U. Maas and R. W. Dibble, Combustion physical and chemical fundamentals, modeling and simulation, experiments, pollutant formation, Berlin, Springer-Verlag, 333-337(2006).

4. L.R. Sassykova, Zh. T. Basheva, M.K. Kalykberdyev, M. Nurakhmetova, A.T. Massenova and K.S.Rakhmetova, Bulgarian Chemical Communications, 50(1), 82(2018).

5. S. Sendilvelan, L. R. Sassykova and M. Prabhahar, Series of Geology and Technology Sciences, 435(3), 6(2019), DOI:10.32014/2019.2518-170X.61.

6. M.A. Abul, Hamayel, Chemical Engineering \& Technology, 25(1), 65(2002), DOI: 10.1002/15214125(200201)25:1<65::AID-CEAT65>3.0.CO;2-P.

7. L. R. Sassykova, S. Sendilvelan, K. Bhaskar, A. S. Zhumakanova, Y. A. Aubakirov, T. S. Abildin, Sh. N. Kubekova, Z. T. Mataeva and A. A. Zhakupova, Series of Geology and Technology Sciences, 434 (2), 181(2019), DOI: 10.32014/2019.2518-170X.53.

8. Ch. Song, Catal. Today, 86, 211(2003), DOI: 10.1016/S0920-5861(03)00412-7.

9. K. Bhaskar, S. Sendilvelan and L.R. Sassykova, News of the National Academy of Sciences of the Republic of Kazakhstan, Series of Geology and Technical Sciences, 428(2), 6(2018), DOI: $10.32014 / 2018.2518-170 X$.

10. Y.W.Li and B.Delmon, J. Mol. Catal. A, 127(1-3),163(1997), DOI:10.1016/s1381-1169(97)00121-0.

11. M.I. Tulepov, D.A. Baiseitov, Sh.E. Gabdrashova, L.R. Sassykova, Y.V. Kazakov, S. Tursynbek, K. Toshtay, I.O. Pustovalov, F.Y. Abdrakova, Z.A. Mansurov and A.B. Dalton, Rasayan J. Chem., 10(4), 1145(2017), DOI: 10.7324/RJC.2017.1041878.

12. M.P. Yunusov, Sh.B. Djalalova, Kh.A. Nasullaev, Gulyamov Sh.T., N.F. Isaeva and E.I. Mirzaeva, Catalysis for Sustainable Energy, 3(1), (2016), DOI:10.1515/cse-2016-0003.

13. E.Rodriguez-Castellon, A. Jimenez-Lopez and D. Eliche-Quesada, Fuel, 87, 1195(2008).

14. V. S. Yemelyanova, B. T. Dossumova, T. V. Shakiyeva, L.R. Sassykova and S. Sendilvelan, International Journal of Mechanical and Production Engineering Research and Development, 9(4), 1079(2019), DOI:10.24247/ijmperdaug2019111.

15. V. S. Yemelyanova, B. T. Dossumova, T. V. Shakiyeva, L.R. Sassykova and S. Sendilvelan, International Journal of Mechanical and Production Engineering Research and Development, 9(4), 1027(2019), DOI:10.24247/ijmperdaug2019105.

HYDROFINING OF PETROL FRACTIONS OF OIL 
RASĀYAN J. Chem.

Vol. 12 | No. 3 |1478 - 1484| July - September | 2019

16. B. T. Tuktin, N. N. Nurgaliyev, A. S. Tenizbayeva and A. A. Shapovalov, Orient J Chem, 33(4), 1799(2017), DOI:10.13005/ojc/330424.

17. G. D. Zakumbaeva, L. B. Shapovalova, B. T. Tuktin and A.A. Omarova, Petroleum Chemistry, 50(2), 135(2010), DOI:10.1134/s096554411002009x.

18. B.T. Tuktin, G.D. Zakumbaeva and W. Du, China Petroleum Processing and Petrochemical Technology, 3, 49(2006).

19. M. Lassinantti, J. Hedlund and J. Sterte, Micropores and Mesopores Materials, 38(1), 25(2000), DOI: $10.1016 / \mathrm{S} 1387-1811(99) 00296-6$.

20. T.C. Ho, Catal. Today, 130, 206(2008), DOI:10.1016/j.cattod.2007.06.076.

21. H. Topsoe, Appl.Catal. A., 322, 3(2007), DOI:10.1016/j.apcata.2007.01.002.

22. V.I. Erofeev and L.V. Adyaeva, Russian Journal of Applied Chemistry,76(7), 1083(2003).

23. I. E. Maxwell and W.H.J. Stork, Studies in Surface Science and Catalysis, 137, 747(2001), DOI: 10.1016/S0167-2991(01)80259-7.

24. Zh. Kh. Tashmukhambetova, N. K. Zhakirova, L. R. Sassykova, K. A. Kadirbekov, Y.A. Aubakirov and A.S. Zhumakanova, Orient J. Chem., 33(6), 2803(2017), DOI:10.13005/ojc/330613.

25. H. Itoh, C.V. Hidalgo, T. Hattori, M. Niwa and Y.J. Murakami, Journal of Catalysis, 85(2), 521(1984), DOI: 10.1016/0021-9517(84)90241-0.

26. L.R. Sassykova, A.M. Nalibayeva and Sh.A. Gil'mundinov, Bulgarian Chemical Communications, 49(3), 583(2017).

27. D. Baiseitov, M. Tulepov, L. Sassykova, Sh. Gabdrashova, K. Kudaibergenov and Z. Mansurov, Revue Roumaine de Chimie, 62(3), 249(2017).

28. F.N. Guerzoni and J. Abbot, Journal of Catalysis, 139(1), 289(1993), DOI:10.1006/jcat.1993.1024.

29. P. Afanasiev and I. Bezverkhyy, Appl. Catal. A, 322, 129(2007), DOI:10.1016/j.apcata.2007.01.015.

30. S. Sendilvelan and K. Rajan, Rasayan J. Chem., 10(1), 190(2017), DOI:10.7324/RJC.2017.1011609.

31. M. Jacoby, Chemical \& Engineering News, 80(37), 30(2002), DOI:10.1021/cen-v080n037.p030.

32. R.K. Ibrasheva, Z.T. Mataeva and K.A. Zhubanov, Eurasian Chemico-Technological Journal, 3(2), 97(2001), DOI: $10.18321 /$ ectj551.

33. I. Amghizar, L. A. Vandewalle, K.M. V.Geem and G. B. Marin, Engineering, 3(2), 171(2017), DOI: 10.1016/j.eng.2017.02.006.

34. A.N. Kharat, P. Pendleton, A. Badalyan, M. Abedini and M.M. Amini, Journal of Catalysis, 205(1), 7(2002), DOI:10.1006/jcat.2001.3317.

35. L. Sassykova, S. Sendilvelan, M. Telbayeva, K. Dossumov and K. Bhaskar, Journal of Chemical Technology \& Metallurgy, 54(3), 539(2019).

36. J.-E. Otterstedt, Yan-Ming Zhu and J. Sterte, Applied Catalysis, 38(1), 143(1988), DOI:10.1016/s0166-9834(00)80993-8.

[RJC-5236/2019] 